\title{
Human security in Africa: issues and problems
}

\author{
Adebowale Adeyemi-Suenu \\ Department of History and International Studies, Faculty of Arts, \\ Lagos State University, Lagos, Nigeria \\ E-mail address: blackman_wale@usa.com
}

\begin{abstract}
The problem of human security is though a global phenomenon, but it is more pronounced in Africa because of its numerous problems of development. This paper however articulates these problems from colonial, post-colonial, and contemporary issues confronting African states. These issues are examined within the vortex of wars, small arms, problems of economic development, and gradual continental extinction. All these are issues and problems in human security in Africa.
\end{abstract}

Keywords: Human security; Africa; Small arms; Wars; Conflict

\section{INTRODUCTION}

The concept of security has in recent times greatly occupied the focus and intellectual works of scholars because of the dimensions it has assumed and the colourations it has also taken. Debates on security in relation to international discourse enable scholars to view the concept beyond its traditional spheres. Security, traditionally, is usually viewed within the contest of protection and this understanding enables it to be already word in the works of scholars in criminology, psychology, strategic discourses etc. Although, scholars of industrial sociology and Human resources have greatly not been left out in its usage while social workers and those concerned with internal protection of human capital and properties even beyond the frontier of a given boundary are very familiar with this concept because issues and problems are often viewed from this conceptual premise. The increasing problems confronting internal community have also increased the degree of scholarship in the area security debates. Contemporary international debates have also largely been centred on the security problems which the ever changing indices of international discourses and problems have brought to bear on the international scene. These situations have tremendously alerted the increasing concern of international and local statesmen not only to attend to these problems but to also search for solutions.

The diminishing scare development resources, wars among nations that have assumed different dimensions, the rise in the activities of the terrorists and their networks, inter and intra-tribal wars, crisis over the allocation of values, conflict and crimes along the borders to mention a few have all affected human capital and this created a serious concern which necessitates researches on reasons, effects and possible solutions [1]. However, at the centre of the entire problem is man who is also the creator of the problem. The security of this specie attracted the attention of scholars and statesmen who needed to be protected from 
being consumed by what he has created. This work is divided into four parts. The first part is the introduction while the second deals with concept of human security. The third is the problems of human security and the last part deals with the conclusion.

\section{HUMAN SECURITY}

Human security refers to the protection and safety of man. The neo-liberal thinkers such as Hubert [2] and Hollfelm [3] are of the view that the consummation of the Human security lies in the adoption of liberal democratic principles. To the two scholars, the sense of participation and belongings increases and this reduces his disposition to activities capable of endangering him as most of his problem can be addressed and resolved within the existing democratic structures and institutions created for the protection of man. This position appears, though, interesting but the following questions collapse the above opinion presented by the two scholars. Has developed democracies resolves the problems of wars and internal violence that endangers man?

Secondly, has the protection of man not at the centre of all welfarist liberal policies? Thirdly, has the problems confronting international space exclusive of the great democracies? Be that as it may, fundamentally, no institutional or democratic procedures have completely resolved the problems of Human security.

The problems of Human security according to Ayoob are both generic and global [4]. Human activities attract conflicts as a result of conflicting interests pursued by man just as the interest of states conflicts within the context of interest and wants by states. Thus the concept of human security underscores the desirability to preserve man and protect man against activities and problems capable of exterminating man. Psycho- analyst argues that man even need to be secured against himself and his destructive activities and pains he brings unto himself [5]. The social welfarists such as Benham Graill have argued that welfarist ideology conceptual policy is largely informed by the need for Human protection [6]. To him, social policies are aimed at Human protection [7].

Social contract theorists' central theses also put man at the centre of their discourses irrespective of the departures relative to their perception of man. For Thomas Hobbes, The brutish states of nature, its nasty and short features are the creation of man. Heddley Bull also got it clear in his anarchical understanding of the contemporary international order. Thus, man has to be protected because man is the most endangered by his own politics.

In Africa, Human security has been at the centre of contemporary policy and vision of the AU so much so that scholars such as Samuel [8] was of the opinion that political modernization and transformation of the Organization of African Unity to African Union was fundamentally underscored by the need to protect and secure Africans from several problems confronting the continent.

OAU was considered moribund, ineffective and incapable of effectively responding to the myriad of problems confronting Africans and the African states.

These problems are problems of institutional transformation or modernization, economic underdevelopment, social degeneration, political development, small arms, child soldiers' menace, communal and inter-communal conflicts, the rise of mercenaries, women combatants, religious crisis, and the rising activities of the terrorist networks among others. Today, the problem of Human security is more important than ever before because of the rising menace of geographical extinction and social irrelevance amongst the committee of nations. 


\section{HUMAN SECURITY IN AFRICA}

Problems of Human security in Africa appear plethora. It ranges from the crisis of small arms to the ever increasing violence which the continent is notoriously known for. The problems of small arms have attracted debates among scholars but what are important are the security problems it has created for Africa.

From the time of Socrates and the sophists, there have been ideological conflict between the world as driven by the mundane forces of politics and economics and as idealized through the fine grain 'ought' of ethics and morality. Socrates paid the supreme price in trying to safeguard the spicy description of morality from the attack of bland subjectivism of practical politics. Machiavelli's The Prince presented modern man with concise prescription on the separation of politics from morality. Today, if the arms trade has a certain precipitous correlation with the volume of conflicts in contemporary society, it is to political economy that we should direct our queries rather than to ethics as the science of morality.

Small arms and sales of arms have been a serious source of Human insecurity in Africa. The sales of which have been condemned but the need for it which has serious political economic undertones is yet to be seriously addressed. Why the need for arms and the need for its sales are concomitant questions

Which are yet to be answered? However, the security problems it has created notwithstanding, how it has endangered Africa and her citizens though an issue, but the political economy of trade and the nature of man which predisposes him to acquire arm for the prosecution of his desire and ego and for the sustenance of his hold on power are issues that should not be subjected to moral understanding but rather within the context of political economy of conflict and violence in Africa.

The arms trade refers to the exchange of weapons of war between manufacturers, middle persons, and the consumers of arms. Historically, the arms trade involved the common trade in gun powder, bow and arrows. During the cold war era, arms export formed part of the influence mechanism utilized by the ideological blocs under what had been the race towards mutually assured destruction (MAD) [9]. Today, the international trade in arms can be directly linked to the economics of conflicts and war. Understandably, the humanitarian tragedies facing large populations in various conflict zones across the world provoked the question of the morality of the arms trade.

The leaps in technology have transformed contemporary arms trade to include highly destructive machine guns, pieces of artillery, landmines and other sophisticated lethal weaponry. The flow and circulation of these weapons intensified in the post-cold war era with the release to the market of excess arms from both the WTO and NATO blocs. These weapons have been exported mainly to developing nations, fuelling intra state tensions and triggering violent conflicts, thus weakening the political and security structures of these countries.

Conventional arms export to Africa and other developing countries raised special moral and diplomatic problems. How can states with very low human development index (HDI) be encouraged to grow when more arms are exported to them on a daily basis than food, medicines and life enhancing infrastructures put together? [10]. Raymond Smith, an arms salesman in Venezuela, believes that trading in arms is intended to regulate and not to cause conflict. Smith sees arms not as a means to start a war, but a means to stopping a war [11]. Sam Cummings, U.K arms dealer and owner of inter arms trading firms, attributes the growth 
of arms trade to some deep-seated tendencies in human beings [12]. According to Cummings, the arms business is founded on human folly.

That is why its depths will never be plumbed, and why it will go on forever. All weapons are defensive, and all spare parts are non-lethal. The question is, in the light of experiences with arms in the conflict in former Yugoslavia, Rwanda, Liberia, Colombia, SriLanka, Democratic Republic of Congo, and more recently, Ivory Coast and Iraq, should the arms trade go on as if it was trade on innocuous baby toys? This is a cross-road where the protections of Africans come in. No wonder, African statesmen vigorously viewed human protection as a serious responsibility.

Robert Kaplan is critical of wealthy Nations whose predatory policy interventions have triggered humanitarian tragedies in part of the developing world. The result has been internal conflict and instability for majority of the client states. Not only in Sierra-Leone, but also the DRC (former Zaire, Angola, Apartheid South Africa, Afghanistan and Iraq, did the world witnessed the constructive engagement with detestable regimes by international actors [13]. The post-cold war scenario engendered severe adverse economic and political difficulties for many developing countries that lost their subsidies due to the sudden end of the regime of ideological proxies. The inability of these states to contain the new Liberia onslaught resulted in violent intra state conflict and challenge of the traditional basis of authority.

The international engagement of the military are implicated in the small arms tracking exercises in Nigeria among the sources that furnished the armouries of actors in the episodic violent communal conflicts that intensified with the inception of Democracy in May, 1999. Apart from community conflict, criminal activities such as robberies and political assassinations are exacerbated by the preponderance in the hands of unauthorised persons. Worse still, youth unemployment and alienation make the proliferation of guns easily available to idle and frustrated boys and girls. In such a situation, the security apparatus is stretched to its wits' end resulting in lapses in community security. The logical outcome of this is to resort to private security, vigilante and the militia for citizen security needs [14]. The General Assembly resolutions 42/75 of 1988, which addresses arms trade, request member states to consider "ways and means of providing for more openness and transparency with regards to world- wide arms transfer requests the Secretary General to carry out thereafter, with the assistance of governmental experts, a study on ways and means of promoting transparency in International transfer of conventional arms on a universal and nondiscriminatory basis, including the problems of illicit arms trade" [15].

The United Nations has engaged with the issue of arms trade from its inception. Far reaching resolutions have been passed by the U.N regarding the trade in conventional arms, but not being a legislative body constrains it from passing laws that directly regulates arms export. Generally, arms sales in Africa have created serious human security problems as several examples above have shown. The dimensions of the problems underscore the relevance of human security problems in Africa. The relevance of this can be viewed against the background of economic under-development, low development indices, decimation of human development capital and other reasons. Another problem that poses serious human security challenge is the inter border war in Africa. A critical examination of inter border crisis in Africa reveals grievous loss of human beings during border wars.

It is also a source of importing arms into Africa. All forms of illicit activities are going on along borders in Africa. Terrorism strives along the borders just like smuggling, piracy and hijacking that are features of the problems associated with border crisis in Africa. 


\section{CONCLUSIONS}

Human Security problems in Africa and its relevance can be understood within the context of the security challenges facing African continent and what it posit for human security and protection. The challenges of human security as an index for development is constrained by wars, communal clashes and mostly by arms sales which makes the prosecution of wars an ultimate in the resolution of crisis among the contending forces in Africa. The political economy of war and sales of arms explains the availability of the lethal weapons and the conditions that makes it already available.

While noting the importance and relevance of Human security in Africa, the A.U forced African elites to accept the Human Security doctrines as a desirable norms and guiding principles in the protection of Africans against of all forms of violence and wars in Africa. The establishment of A.U was being partly informed by Human security concerns. Human security elements were highlighted in key A.U documents to show and demonstrated the primacy and relevance of Human Security Issues in Africa.

\section{References}

[1] Richard A., Issues in Human Security. Beyond Theories, London; Chalton Press. pp. 113.

[2] Hubert G., Neo- Liberalism and African Security Problems, Willfred, 2011, pp. 32.

[3] Hollfem R., Security Issues in Africa: Neo-Liberal Perspective. Clarendon; London 2012, pp. 43.

[4] Ayoob A., Human Security in Africa, Bluecrest, New York, 2009, pp. 72.

[5] Benham G., On Human Protection in Africa, G and Richard, London. 2009, pp. 72.

[6] Ibid.

[7] Ibid.

[8] Samuel R., Dimensions of Violence and Security in Africa. Woodwords, 2010, pp. 67.

[9] Oshita O., The Arms Trade and Common Security: The Case of SALW in West Africa, Calabar, Nigeria, Malthouse, 2010, pp. 170.

[10] Samson A., The Arms Barssar, London; Hodder and Stuohgton, 1977 and H. Suganami, The Causes of war, Oxford; Claredon Press, 1996.

[11] Ibid., pp. 11.

[12] Campaign Against Arms trade, The Privatization of violence: New Mercenarism and the State, London; Campaign Against Arms Trade (CAAT), 1999 and J Conely and G.

Smith, Politics and the Environment: From Theory to Practice, second Edition, London; Routledge, 2003.pp.74

[13] Kaplan R., The Coming Anarchy: Shattering the Dreams of the Post-Cold war, New York, Vintage books, 2001 and G. Rupp, Report by the President of the U.N in Integrated Regional information Network, www.the irc.org, 2003.

[14] U.N Documents. A/RES/43/75 and A/32/88/Rev.1,para.43. 